\title{
Loss of integrin $\alpha_{v} \beta_{8}$ on dendritic cells causes autoimmunity and colitis in mice
}

\author{
Mark A. Travis ${ }^{1, \dagger}$, Boris Reizis $^{2}$, Andrew C. Melton ${ }^{1}$, Emma Masteller ${ }^{3}$, Qizhi Tang ${ }^{3}$, John \\ M. Proctor ${ }^{4}$, Yanli Wang ${ }^{1}$, Xin Bernstein ${ }^{1}$, Xiaozhu Huang ${ }^{1}$, Louis F. Reichardt ${ }^{4}$, Jeffrey A. \\ Bluestone $^{3}$, and Dean Sheppard ${ }^{1}$ \\ 1 Lung Biology Center, Department of Medicine, University of California San Francisco, 1550 4th Street, \\ Room 545, San Francisco, California 94158, USA.
}

2Department of Microbiology, Columbia University, 701 West 168th Street, Room 609, New York, New York 10032, USA.

3Diabetes Center, Department of Medicine, 513 Parnassus Avenue, University of San Francisco, San Francisco, California 94143, USA.

4Howard Hughes Medical Institute, Department of Physiology, University of California, San Francisco, California 94158, USA.

\begin{abstract}
The cytokine transforming growth factor- $\beta$ (TGF- $\beta$ ) is an important negative regulator of adaptive immunity ${ }^{1-3}$. TGF- $\beta$ is secreted by cells as an inactive precursor that must be activated to exert biological effects ${ }^{4}$, but the mechanisms that regulate TGF- $\beta$ activation and function in the immune system are poorly understood. Here we show that conditional loss of the TGF- $\beta$-activating integrin $\alpha_{\mathrm{v}} \beta_{8}$ on leukocytes causes severe inflammatory bowel disease and age-related autoimmunity in mice. This autoimmune phenol-type is largely due to lack of $\alpha_{\mathrm{v}} \beta_{8}$ on dendritic cells, as mice lacking $\alpha_{\mathrm{v}} \beta_{8}$ principally on dendritic cells develop identical immunological abnormalities as mice lacking $\alpha_{\mathrm{v}} \beta_{8}$ on all leukocytes, whereas mice lacking $\alpha_{\mathrm{v}} \beta_{8}$ on T cells alone are phenotypically normal. We further show that dendritic cells lacking $\alpha_{v} \beta_{8}$ fail to induce regulatory $T$ cells ( $T_{R}$ cells) in vitro, an effect that depends on TGF- $\beta$ activity. Furthermore, mice lacking $\alpha_{v} \beta_{8}$ on dendritic cells have reduced proportions of $T_{R}$ cells in colonic tissue. These results suggest that $\alpha_{v} \beta_{8}$-mediated TGF- $\beta$ activation by dendritic cells is essential for preventing immune dysfunction that results in inflammatory bowel disease and autoimmunity, effects that are due, at least in part, to the ability of $\alpha_{v} \beta_{8}$ on dendritic cells to induce and/or maintain tissue $\mathrm{T}_{\mathrm{R}}$ cells.
\end{abstract}

\footnotetext{
Correspondence and requests for materials should be addressed to D.S. (E-mail: dean.sheppard@ucsf.edu).

Present address: Wellcome Trust Centre for Cell-Matrix Research, Faculty of Life Sciences, University of Manchester, A3051 Smith Building, Oxford Road, Manchester M13 9PT, UK.

Author Contributions M.A.T. performed all of the experiments described and wrote most of the manuscript; B.R. generated the CD11cCre mice and contributed to the design and interpretation of studies using those mice; A.C.M. contributed to the studies of colonic inflammation, colonic $\mathrm{T}_{\mathrm{R}}$ cells and designed and performed all of the $\mathrm{qPCR}$ studies described; E.M. helped design, perform and interpret the in vitro $\mathrm{T}_{\mathrm{R}}$ cell induction assays; Q.T. helped to design, perform and interpret the studies analysing the nature of the immunological defects described; J.M.P. generated the conditional Itgb8 knockout mice and helped in the design and interpretation of genotyping assays and crosses to Cre-expressing lines; Y.W., X.B. and X.H. helped in the design, performance and interpretation of all of the studies of tissue morphology; L.F.R. oversaw the generation of the conditional Itgb8 knockout mice and contributed to the design and interpretation of studies using these animals; J.A.B. contributed to the design and interpretation of the studies characterizing the immunological abnormalities seen and analysing the contribution of $\mathrm{T}_{\mathrm{R}}$ cells; D.S. oversaw the design and interpretation of all studies described and ovsersaw writing of the manuscript.
}

Author Information Reprints and permissions information is available at http://www.nature.com/reprints. The authors declare no competing financial interests. 
The critical pathways for activation of latent TGF- $\beta$ at specific sites in vivo remain controversial. One important mechanism for activation of two of the three mammalian TGF$\beta$ isoforms (TGF- $\beta 1$ and TGF- $\beta 3$ ) is through interaction with members of the integrin recaptor family ${ }^{5-7}$. The in vivo importance of TGF- $\beta$ activation by integrins has been recently demonstrated in mice with a mutated integrin-binding motif in TGF- $\beta 1$ (ref. 8). These mice completely phenocopy $T g f b 1^{-/-}$mice, which die from multi-organ inflammatory disease ${ }^{1}$, showing that integrin-mediated TGF- $\beta$ activation is vital to maintain immune homeostasis. However, the integrin(s) responsible for TGF- $\beta$ activation in the immune system in vivo, where these integrins are expressed, and the mechanisms by which integrin-mediated TGF- $\beta$ activation maintains immune homeostasis remain a mystery.

The integrin $\alpha_{\mathrm{v}} \beta_{6}$ has previously been shown to activate TGF- $\beta$ (ref. 6), but this integrin is restricted to a subset of epithelial cells and is not expressed on immune cells. Furthermore, the inflammatory phenotype of mice lacking $\alpha_{\mathrm{v}} \beta_{6}$ is mild compared to mice lacking TGF- $\beta 1$ or TGF- $\beta 3$ (ref. 5). The $\alpha_{v} \beta_{8}$ integrin can also activate TGF- $\beta$ (ref. 7). Mice completely lacking $\alpha_{\mathrm{v}} \beta_{8}$ die before or shortly after birth from defects in brain vascular development ${ }^{9}$, so tissuespecific deletion was required to determine whether $\alpha_{v} \beta_{8}$-mediated TGF- $\beta$ activation has a function in regulating adaptive immunity. Polymerase chain reaction with reverse transcription (RT-PCR) analysis revealed that $\beta_{8}$ was expressed in total splenocytes, $\mathrm{CD} 4^{+} \mathrm{T}$ cells and dendritic cells (Supplementary Fig. 1a) but was present at very low or undetectable levels in macrophages, $\mathrm{CD} 8^{+} \mathrm{T}$ cells, natural killer cells and $\mathrm{B}$ cells. To assess the in vivosignificance of $\alpha_{\mathrm{v}} \beta_{8}$ expression in the immune system, we produced mice with conditional loss of $\beta_{8}$ on leukocytes by crossing mice homozygous for a floxed $\beta_{8}$ (Itgb8) allele ${ }^{10}$ with mice expressing Cre recombinase under the control of the Vav1 promoter $^{11}$ (hereafter called (Vav1-cre) Itg $b 8^{f l f l}$ ). Quantitative (q)RT-PCR revealed efficient knockdown (>98\%) of Itgb8 messenger RNA expression in $\mathrm{CD}^{+} \mathrm{T}$ cells and dendritic cells from (Vav1-cre)Itgb $8^{f l f l}$ mice (Supplementary Fig. 1b).

(Vav1-cre)Itgb $8^{f l f l}$ mice were phenotypically normal until 4-5 months of age, when they began to develop a progressive wasting disorder (Fig. 1a). (Vavl-cre)Itgb $8^{f l f l}$ mice also developed spleno-megaly, massive enlargement of mesenteric lymph nodes (Fig. 1b) and accumulations of mononuclear cells adjacent to portal triads of the liver (Fig. 1c). By 10 months of age, all surviving (Vav1-cre)Itgb $8^{f l f l}$ mice developed severe colitis, characterized by cellular infiltration of the colonic wall with eosinophils and plasma cells, and formation of colonic cysts (Fig. 1d). These mice also developed high levels of auto-antibodies directed against double-stranded DNA and ribonuclear proteins (Fig. 1e). These findings are remarkably similar to phenotypes described for mice with a partial loss of TGF- $\beta$ signalling in T cells as a result of expression of a dominant negative TGF- $\beta$ receptor ${ }^{12}$, and for mice lacking the key TGF$\beta$ signalling protein Smad4 in T cells ${ }^{13}$. Mice lacking Smad4 in T cells also had increased tumorigenesis ${ }^{13}$, a finding we did not observe.

PCR of stool samples revealed the presence of the common intestinal bacteria Helicobacter hepaticus and Helicobacter ganmani from all control and experimental mice tested. These organisms, endemic in our facility and in over $85 \%$ of mouse research colonies worldwide 14,15 , are not pathogenic in most strains of mice, but have been reported to cause colitis and hepatic inflammation in some immune-suppressed strains ${ }^{16}$. We therefore cannot exclude the possibility that the presence of these organisms, or other unmeasured microbial flora, contribute to the severity of colonic and/or hepatic pathology in (Vav1-cre)Itgb $8^{f l f l}$ mice. Such a response could be relevant to inflammatory bowel diseases in humans, where abnormal responses to normally non-pathogenic intestinal flora have been suggested to have a role ${ }^{17}$.

Mice with impaired T-cell responsiveness to TGF- $\beta$ were also shown to have increased numbers of activated peripheral T cells, increased circulating levels of IgA and IgG1, and 
increased numbers of T cells that produce interleukin-4 (IL-4) and/or interferon- $\gamma(\text { IFN- } \gamma)^{12}$. (Vavl-cre)Itgb $8^{f l f l}$ mice (4-6 months old) also had enhanced numbers of activated/memory $\mathrm{CD} 4^{+}$and $\mathrm{CD} 8^{+} \mathrm{T}$ cells (Fig. 2a), and increased numbers of $\mathrm{CD} 4^{+} \mathrm{T}$ cells producing IFN- $\gamma$ and IL-4, and $\mathrm{CD}^{+}$cells producing IFN- $\gamma$ (Fig. $2 \mathrm{~b}$ and Supplementary Fig. 2). (Vavl-cre) Itgb $8^{f l f l}$ mice also had increased levels of circulating IgE, IgG1 and IgA (Fig. 2c), whereas levels of IgM, IgG2a, IgG2b and IgG3 were not significantly different (Supplementary Fig. 3). Again, these features were virtually identical to those described in mice with a partial loss of TGF- $\beta$ signalling in T cells, suggesting that $\alpha_{v} \beta_{8}$ on leukocytes has an important role in activating TGF- $\beta$ for presentation to T cells. This phenotype is not due to the mixed genetic background analysed in these initial experiments, because mice bred five generations to pure C57BL/6 background have a similar immune phenotype and also develop colitis (Supplementary Fig. 4).

We next assessed whether loss of $\alpha_{\mathrm{v}} \beta_{8}$ on either dendritic cells or T cells was responsible for the in vivo phenotype observed in (Vavl-cre)Itgb $8^{f l f l}$ mice by crossing mice homozygous for the Itgb8-floxed allele with mice expressing Cre recombinase principally in T cells (CD4-Cre) 18 or dendritic cells (CD11c-Cre) ${ }^{19}$. By qRT-PCR we saw a greater than $99 \%$ reduction in Itgb8 mRNA levels in $\mathrm{CD}^{+}{ }^{+} \mathrm{T}$ cells from Itgb $8^{f l / f l}$ mice expressing CD4-Cre ((CD4-cre) Itg $b^{f l} l f l$ ), with a modest reduction in dendritic cells (Supplementary Fig. 5a). Greater than $99 \%$ reduction in Itg $b 8 \mathrm{mRNA}$ levels was found in dendritic cells from Itgb $8^{f l} / \mathrm{fl}$ mice expressing CD11c-Cre $\left((C D 11\right.$ c-cre $)$ Itgb $\left.8^{f l f f l}\right)$, with a modest reduction in $\mathrm{CD} 4^{+} \mathrm{T}$ cells (Supplementary Fig. 5b). Therefore, $(C D 4-c r e)$ Itgb $8^{f l / f l}$ mice completely lacked $\beta_{8}$ expression in $\mathrm{CD} 4^{+} \mathrm{T}$ cells, but only partially in dendritic cells, whereas (CD11c-cre) Itgb8fl/fl mice completely lacked $\beta_{8}$ expression in dendritic cells, but only partially in $\mathrm{CD} 4^{+} \mathrm{T}$ cells.

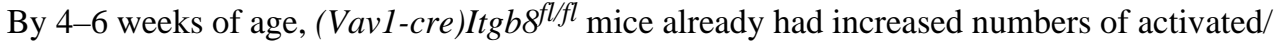
memory T cells, increased T-cell production of IFN- $\gamma$ and/or IL-4, and increased circulating levels of IgE, IgG1 and IgA (Fig. 3). In contrast, (CD4-cre)Itgb $8^{f l / f l}$ mice were indistinguishable from control mice, and showed no signs of illness up to at least 14 months of age. (CDI1c-cre)Itgb $8^{f l f l}$ mice show an identical immunological phenotype to mice lacking $\beta_{8}$ integrin on all leukocytes, with significantly increased numbers of activated/memory T cells (Fig. 3a), increased T cells expressing IFN- $\gamma$ and/or IL-4 (Fig. 3b), and increases in serum IgE, IgG1 and IgA levels (Fig. 3c). Older (CDI lc-cre)Itgb $8^{\text {fllfl }}$ mice (6-7 months) manifested an identical phenotype to age-matched mice lacking $\beta_{8}$ on all leukocytes, with significant weight loss, enlarged spleen and mesenteric lymph nodes, infiltrates in portal triads of the liver, and development of colonic inflammation (Supplementary Fig. 6). These results suggest that expression of the $\alpha_{\mathrm{v}} \beta_{8}$ integrin on dendritic cells is vital for the negative regulation of adaptive immunity. Loss of $\alpha_{v} \beta_{8}$ on T cells is not by itself sufficient to cause any aspects of this phenotype. However, because CD11c-Cre did cause a modest reduction in $\beta_{8}$ expression in CD4 ${ }^{+}$T cells, we cannot exclude a minor contribution from partial loss of $\alpha_{v} \beta_{8}$ on these cells.

Mice lacking $\mathrm{T}_{\mathrm{R}}$ cells also develop severe autoimmunity ${ }^{20}$, and recent work has shown an important role for TGF- $\beta$ in the biology of $\mathrm{T}_{\mathrm{R}}$ cells $\mathrm{s}^{21-24}$. We therefore examined the ability of control or $\beta_{8}$-deficient dendritic cells to induce $\mathrm{T}_{\mathrm{R}}$ cells from $\mathrm{CD}^{+} \mathrm{T}$ cells in an in vitro $\mathrm{T}$ cell activation assay. Both control and $\beta_{8}$-deficient dendritic cells showed similar populations of myeloid $\left(\mathrm{CD} 11 \mathrm{c}^{\text {high }} \mathrm{CD} 8^{-}\right)$, lymphoid $\left(\mathrm{CD} 11 \mathrm{c}^{\text {high }} \mathrm{CD} 8^{+}\right)$and plasmacytoid

$\left(\mathrm{CD} 11 \mathrm{c}^{\text {low }} \mathrm{B} 220^{+}\right.$) dendritic cells (Supplementary Fig. 7a), with comparable expression of the activation markers CD86 and major histocompatibility complex (MHC) class II

(Supplementary Fig. 7b), indicating that lack of $\beta_{8}$ integrin does not affect the development or maturation of dendritic cells. In the presence of control dendritic cells approximately $3 \%$ of $\mathrm{CD}^{+} \mathrm{T}$ cells converted to $\mathrm{T}_{\mathrm{R}}$ cells (determined by expression of the $\mathrm{T}_{\mathrm{R}}$-cell-specific reporter gene Foxp3-Gfp ${ }^{25}$ ) and induction was inhibited by an anti-TGF- $\beta$ antibody (Fig. 4a). However, in the presence of $\beta_{8}$-deficient dendritic cells, $T_{R}$ cell induction was markedly reduced (Fig. 
4a). Addition of active TGF- $\beta$ to cultures containing either control or $\beta_{8}$-deficient dendritic cells resulted in a similar induction of $\mathrm{T}_{\mathrm{R}}$ cells (Fig. 4b). Co-culture with TGF- $\beta$-luciferase reporter cells also demonstrated decreased TGF- $\beta$ activity generated by $\beta_{8}$-deficient dendritic cells compared to control dendritic cells (Fig. 4c).

To determine whether there was a defect in $\mathrm{T}_{\mathrm{R}}$ cell induction by $\beta_{8}$-deficient dendritic cells in vivo, we analysed CD $4^{+}$Foxp $3^{+} \mathrm{T}_{\mathrm{R}}$ cells in the spleen or colon of young (8-14 weeks) control or (CDI lc-cre) Itgb $8^{f l f l}$ mice. No difference in the proportion of $\mathrm{T}_{\mathrm{R}}$ cells was observed in the spleens, but there was a greater than $50 \%$ reduction in the proportion of $\mathrm{T}_{\mathrm{R}}$ cells recovered from the colonic lamina propria of $\left(C D 11\right.$ c-cre) Itg $b^{f l l f l}$ mice (Fig. 4d). We cannot rule out the possibility that $\mathrm{CD}^{+}$effector cell expansion contributes to the observed reduction in the fractional number of $\mathrm{T}_{\mathrm{R}}$ cells in the colon. However, taken together, our in vitro and in vivo results suggest that activation of TGF- $\beta$ by $\alpha_{\mathrm{v}} \beta_{8}$ on dendritic cells is important for the induction of $T_{R}$ cells in peripheral tissues such as the colon, and that a defect in $T_{R}$ cell induction and/ or maintenance could contribute to the autoimmunity and colitis in (CDI1c-cre)Itgb $8^{f l f f}$ mice.

Because the phenotype we observed is markedly similar to that of mice with impaired TGF$\beta$ signalling in T cells, and $\alpha_{v} \beta_{8}$ on dendritic cells activates TGF- $\beta$, our results suggest a key negative regulatory role for presentation of active TGF- $\beta$ from $\alpha_{\mathrm{v}} \beta_{8}$ on dendritic cells to T cells. Our findings further suggest that the aberrant immune homeostassis we observed may be explained by the known role of TGF- $\beta$ in induction of Foxp 3 expression ${ }^{21}$ and resultant differentiation of $T$ cells to $T_{R}$ cells. However, whereas $T_{R}$ cells in the colon were decreased in $\left(C D 11\right.$ c-cre) Itgb $8^{f l f l}$ mice, numbers of $\mathrm{T}_{\mathrm{R}}$ cells in the spleen were normal. These results may be explained by a difference in the mechanisms underlying the generation of natural/innate $T_{R}$ cells that are the primary contributor to $T_{R}$ cells in the spleen, lymph nodes and circulation, and adaptive $T_{R}$ cells that are critical for maintaining peripheral homeostasis and preventing diseases such as colitis 26,27 . In addition to $T_{R}$ cell abnormalities, the observed autoimmune phenotype could be partially explained by a role for dendritic cell $\alpha_{\mathrm{v}} \beta_{8}$-mediated TGF- $\beta$ activation in the direct regulation of T-cell function, as it is known that TGF- $\beta$ can also directly suppress effector $\mathrm{T}$ cells ${ }^{28}$.

As described earlier, mutation of the RGD integrin-binding site in TGF- $\beta 1$ results in a more severe autoimmune phenotype reminiscent of loss of TGF- $\beta 1$ (ref. 8). Therefore, it is likely that activation of TGF- $\beta$ by other integrins or cell types is also important for the main-tenance of immune homeostasis. For example, the $\alpha_{v} \beta_{6}$ integrin on epithelial cells or the $\alpha_{v} \beta_{8}$ integrin on resident tissue cells might also contribute to $T_{R}$ cell induction and immune suppression at specific sites. Notably, in the absence of the $\alpha_{v} \beta_{8}$ integrin on dendritic cells, mice demonstrate widespread evidence of immune activation, autoimmunity and colitis, suggesting that genetic or acquired abnormalities in $\alpha_{\mathrm{v}} \beta_{8}$ might contribute to the development of inflammatory bowel disease or other autoimmune disorders.

\section{METHODS SUMMARY}

Mice

Mice expressing a floxed allele of $\operatorname{Ig} b 8$ have been described ${ }^{10}$, and were maintained on a mixed CD1, FVB and C57BL/6 background. Vav1-Cre mice were a gift from D. Kioussis ${ }^{11}$. CD4-Cre mice 18 were purchased from Taconic. For some experiments, alleles were bred for five generations to $\mathrm{C} 57 \mathrm{BL} / 6$ mice. $\mathrm{CD} 11 \mathrm{c}-\mathrm{Cre}$ mouse generation is described in a separate manuscript ${ }^{19}$. Foxp3-GFP mice were a gift from A. Rudensky ${ }^{25}$. All mice were maintained under pathogen-free conditions, according to institutional guidelines. 


\section{Cell purification and flow cytometry}

Cells were purified using magnetic beads (Miltenyi) or by flow cytometry. Flow cytometry data analysis was performed using FloJo software (Treestar).

\section{Quantitative RT-PCR}

RNA was isolated using an RNeasy mini kit (Qiagen), and reverse transcribed using Superscript II RT (Invitrogen). Quantitative PCR was performed using a Sybr Green qRT-PCR kit (Invitrogen). Primers used are detailed in the Methods.

\section{Cytokine production assays}

Splenocytes $\left(5 \times 10^{6} \mathrm{ml}^{-1}\right)$ were incubated with $50 \mathrm{ng} \mathrm{ml}^{-1} \mathrm{PMA}$ (Sigma) and $1 \mu \mathrm{M}$ ionomycin (Calbiochem). For intracellular flow cytometry, cells were cultured for $2 \mathrm{~h}$ followed by addition of $2 \mu \mathrm{M}$ monensin (eBioscience) and cultured for another $2 \mathrm{~h}$. For ELISA analysis, cells were cultured for $24 \mathrm{~h}$ and supernatants harvested.

\section{Regulatory T-cell induction assay}

Briefly, non- $\mathrm{T}_{\mathrm{R}} \mathrm{CD}^{+}$cells $\left(\mathrm{CD} 4^{+} \mathrm{GFP}-\mathrm{Foxp}^{-} \mathrm{T}\right.$ cells from GFP-Foxp3 mice $^{25}$ ) were incubated with $\mathrm{CD} 11 \mathrm{c}^{+}$dendritic cells in the presence of anti-CD3 antibody and either control antibody, anti-TGF- $\beta$ antibody or active TGF for 3 days. $T_{R}$ cell induction was measured by flow cytometry analysis of $\mathrm{CD}^{+} \mathrm{GFP}-\mathrm{Foxp} 3^{+}$cells. See Methods for full details of $\mathrm{T}_{\mathrm{R}}$ cell induction and TGF- $\beta$ activation assays.

\section{Colon lamina propria cell preparation}

Colonic lamina propria lymphocytes were isolated as described ${ }^{29}$, with slight modification (see Methods).

\section{Statistical analysis}

All statistics were generated using a Student's $t$-test. All error bars in figures represent s.e.m.

Full Methods and any associated references are available in the online version of the paper at www.nature.com/nature.

\section{Supplementary Material}

Refer to Web version on PubMed Central for supplementary material.

\section{References}

1. Shull MM, et al. Targeted disruption of the mouse transforming growth factor- $\beta 1$ gene results in multifocal inflammatory disease. Nature 1992;359:693-699. [PubMed: 1436033]

2. Marie JC, Liggitt D, Rudensky AY. Cellular mechanisms of fatal early-onset autoimmunity in mice with the T cell-specific targeting of transforming growth factor- $\beta$ receptor. Immunity $2006 ; 25: 441-$ 454. [PubMed: 16973387]

3. Li MO, Sanjabi S, Flavell RA. Transforming growth factor- $\beta$ controls development, homeostasis, and tolerance of $\mathrm{T}$ cells by regulatory $\mathrm{T}$ cell-dependent and -independent mechanisms. Immunity 2006;25:455-471. [PubMed: 16973386]

4. Annes JP, Munger JS, Rifkin DB. Making sense of latent TGF $\beta$ activation. J. Cell Sci 2003;116:217224. [PubMed: 12482908]

5. Huang XZ, et al. Inactivation of the integrin $\beta 6$ subunit gene reveals a role of epithelial integrins in regulating inflammation in the lung and skin. J. Cell Biol 1996;133:921-928. [PubMed: 8666675] 
6. Munger JS, et al. The integrin $\alpha v \beta 6$ binds and activates latent TGF $\beta 1$ : a mechanism for regulating pulmonary inflammation and fibrosis. Cell 1999;96:319-328. [PubMed: 10025398]

7. Mu D, et al. The integrin $\alpha v \beta 8$ mediates epithelial homeostasis through MT1-MMP-dependent activation of TGF- $\beta 1$. J. Cell Biol 2002;157:493-507. [PubMed: 11970960]

8. Yang Z, et al. Absence of integrin-mediated TGF $\beta 1$ activation in vivo recapitulates the phenotype of TGFß1-null mice. J. Cell Biol 2007;176:787-793. [PubMed: 17353357]

9. Zhu J, et al. $\beta 8$ integrins are required for vascular morphogenesis in mouse embryos. Development 2002;129:2891-2903. [PubMed: 12050137]

10. Proctor JM, Zang K, Wang D, Wang R, Reichardt LF. Vascular development of the brain requires $\beta 8$ integrin expression in the neuroepithelium. J. Neurosci 2005;25:9940-9948. [PubMed: 16251442]

11. de Boer J, et al. Transgenic mice with hematopoietic and lymphoid specific expression of Cre. Eur. J. Immunol 2003;33:314-325. [PubMed: 12548562]

12. Gorelik L, Flavell RA. Abrogation of TGF $\beta$ signaling in T cells leads to spontaneous T cell differentiation and autoimmune disease. Immunity 2000;12:171-181. [PubMed: 10714683]

13. Kim BG, et al. Smad4 signalling in T cells is required for suppression of gastrointestinal cancer. Nature 2006;441:1015-1019. [PubMed: 16791201]

14. Bohr UR, et al. Prevalence and spread of enterohepatic Helicobacter species in mice reared in a specific-pathogen-free animal facility. J. Clin. Microbiol 2006;44:738-742. [PubMed: 16517848]

15. Taylor NS, Xu S, Nambiar P, Dewhirst FE, Fox JG. Enterohepatic Helicobacter species are prevalent in mice obtained from commercial and academic institutions in Asia, Europe, and North America. J. Clin. Microbiol 2007;45:2166-2172. [PubMed: 17507523]

16. Whary MT, Fox JG. Detection, eradication, and research implications of Helicobacter infections in laboratory rodents. Lab Anim. (NY) 2006;35:25-36. [PubMed: 16807564]

17. Strober W, Fuss I, Mannon P. The fundamental basis of inflammatory bowel disease. J. Clin. Invest 2007;117:514-521. [PubMed: 17332878]

18. Lee PP, et al. A critical role for Dnmt1 and DNA methylation in T cell development, function, and survival. Immunity 2001;15:763-774. [PubMed: 11728338]

19. Caton ML, Smith-Raska MR, Reizis B. Notch-RBP-J signaling controls the homeostasis of CD8 dendritic cells in the spleen. J. Exp. Med 2007;204:1653-1664. [PubMed: 17591855]

20. Sakaguchi S, et al. Foxp $3^{+} \mathrm{CD} 25^{+} \mathrm{CD} 4^{+}$natural regulatory $\mathrm{T}$ cells in dominant self-tolerance and autoimmune disease. Immunol. Rev 2006;212:8-27. [PubMed: 16903903]

21. Chen $\mathrm{W}$, et al. Conversion of peripheral $\mathrm{CD} 4{ }^{+} \mathrm{CD} 25^{-}$naive $\mathrm{T}$ cells to $\mathrm{CD} 4{ }^{+} \mathrm{CD} 25^{+}$regulatory $\mathrm{T}$ cells by TGF- $\beta$ induction of transcription factor Foxp3. J. Exp. Med 2003;198:1875-1886. [PubMed: 14676299]

22. Nakamura K, et al. TGF- $\beta 1$ plays an important role in the mechanism of $\mathrm{CD} 4^{+} \mathrm{CD} 25^{+}$regulatory $\mathrm{T}$ cell activity in both humans and mice. J. Immunol 2004;172:834-842. [PubMed: 14707053]

23. Fahlen $\mathrm{L}$, et al. $\mathrm{T}$ cells that cannot respond to TGF- $\beta$ escape control by $\mathrm{CD} 4^{+} \mathrm{CD} 25^{+}$regulatory $\mathrm{T}$ cells. J. Exp. Med 2005;201:737-746. [PubMed: 15753207]

24. Marie JC, Letterio JJ, Gavin M, Rudensky AY. TGF- $\beta 1$ maintains suppressor function and Foxp3 expression in $\mathrm{CD}^{+} \mathrm{CD} 25^{+}$regulatory T cells. J. Exp. Med 2005;201:1061-1067. [PubMed: 15809351]

25. Fontenot JD, et al. Regulatory T cell lineage specification by the forkhead transcription factor Foxp3. Immunity 2005;22:329-341. [PubMed: 15780990]

26. Bluestone JA, Abbas AK. Natural versus adaptive regulatory T cells. Nature Rev. Immunol 2003;3:253-257. [PubMed: 12658273]

27. Bluestone JA, Tang Q. How do $\mathrm{CD} 4{ }^{+} \mathrm{CD} 25^{+}$regulatory T cells control autoimmunity? Curr. Opin. Immunol 2005;17:638-642. [PubMed: 16209918]

28. Li MO, Wan YY, Sanjabi S, Robertson AK, Flavell RA. Transforming growth factor- $\beta$ regulation of immune responses. Annu. Rev. Immunol 2006;24:99-146. [PubMed: 16551245]

29. Lefrancois L, Lycke N. Isolation of mouse small intestine intraepithelial lymphocytes, Peyer's patch, and lamina propria cells. Curr. Protocols Immunol. 2001Unit 3.19 doi: 10.1002/0471142735.im0319s 17 
30. Abe M, et al. An assay for transforming growth factor- $\beta$ using cells transfected with a plasminogen activator inhibitor-1 promoter-luciferase construct. Anal. Biochem 1994;216:276-284. [PubMed: 8179182]

\section{Acknowledgements}

We thank D. Kioussis for providing the Vav1-Cre mice and A. Rudensky for providing theGFP-Foxp3 mice. This work was supported by grants from the National Heart, Lung and Blood Institute (to D.S.), the National Institute of Allergy and Infectious Diseases (to J.A.B and B.R.) and funds from the Sandler Program for Asthma Research (to B.R.). M.A.T. was the recipient of an American Lung Association Research Fellowship. 


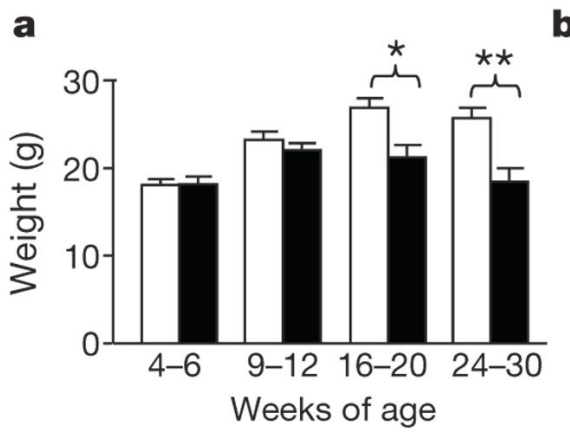

b
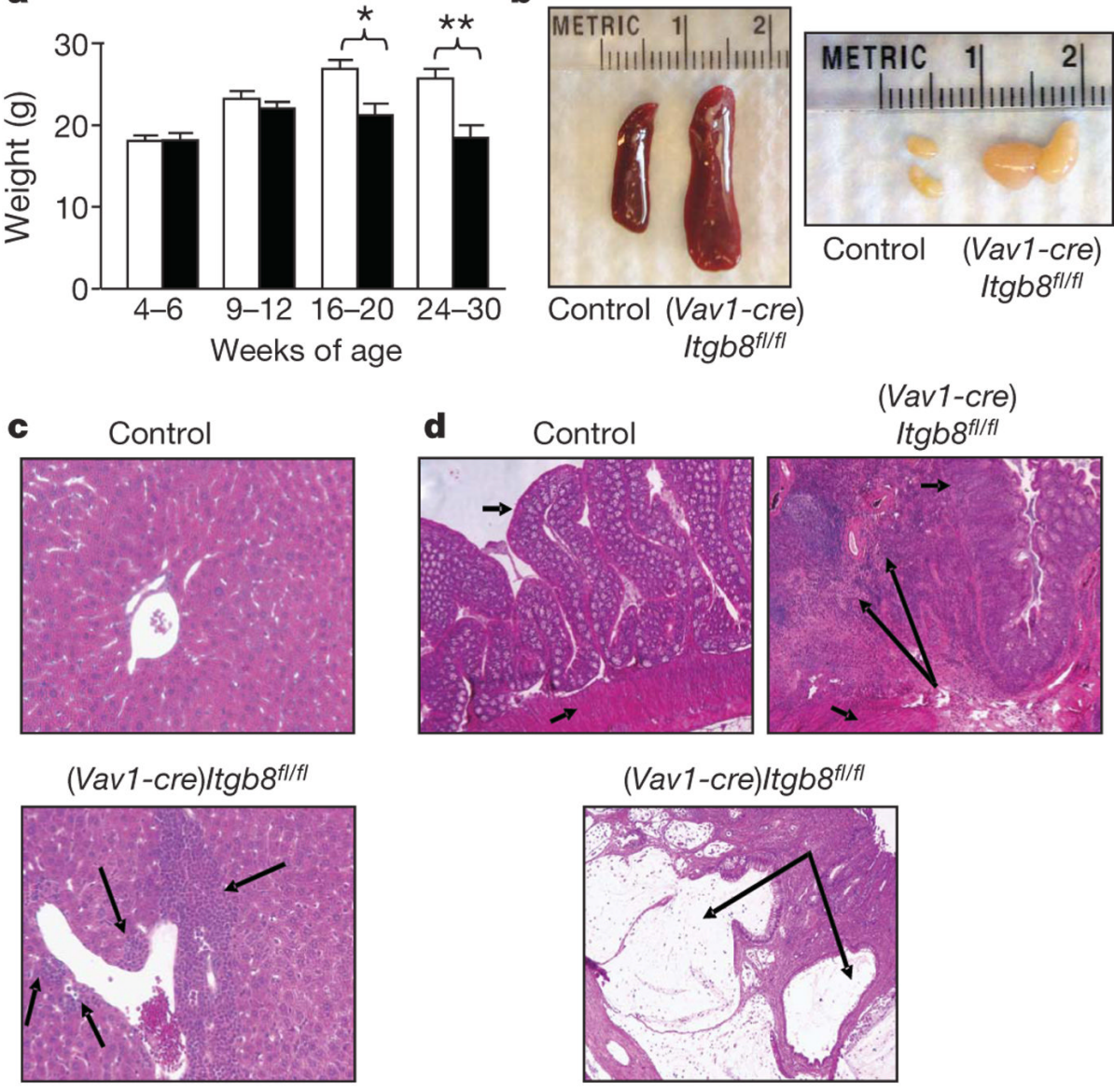

(Vav1-cre)/tgb8 $8^{f|/|}$

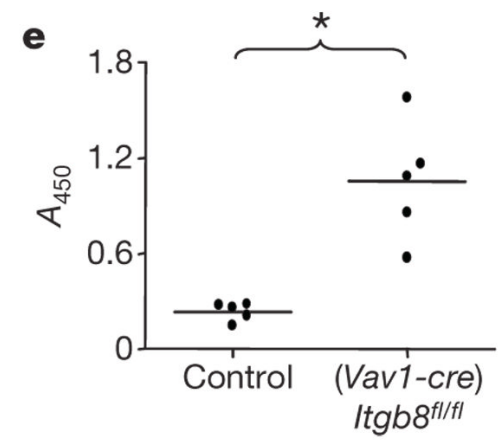

Figure 1. (Vav1-cre)Itgb $8^{f l f l}$ mice develop age-related autoimmunity a, Weight loss in control and (Vav1-cre)Itgb $8^{f l / f l}$ mice (white, control; black, (Vav1-cre) Itgb $8^{f l f l} ; n=7$ per group; asterisk, $P=0.011$; double asterisk, $P=0.0026$ ). Error bars represent s.e.m. b, Lymphoid organs of 5-month-old mice. c, Haematoxylin- and eosin-stained sections of livers $(10$ months, original magnification $\times 200)$. Arrows show cellular infiltrates. d, Haematoxylin- and eosin-stained colon sections $(9$ months, original magnification $\times 50)$. Short arrows, epithelium (top arrow) and smooth muscle (bottom arrow); large arrows, cellular infiltrates (top panel) and large cyst (bottom panel). e, ELISA for anti-dsDNA and antiribonuclear protein (9-12 months, $n=5, P=0.0013$ ). 

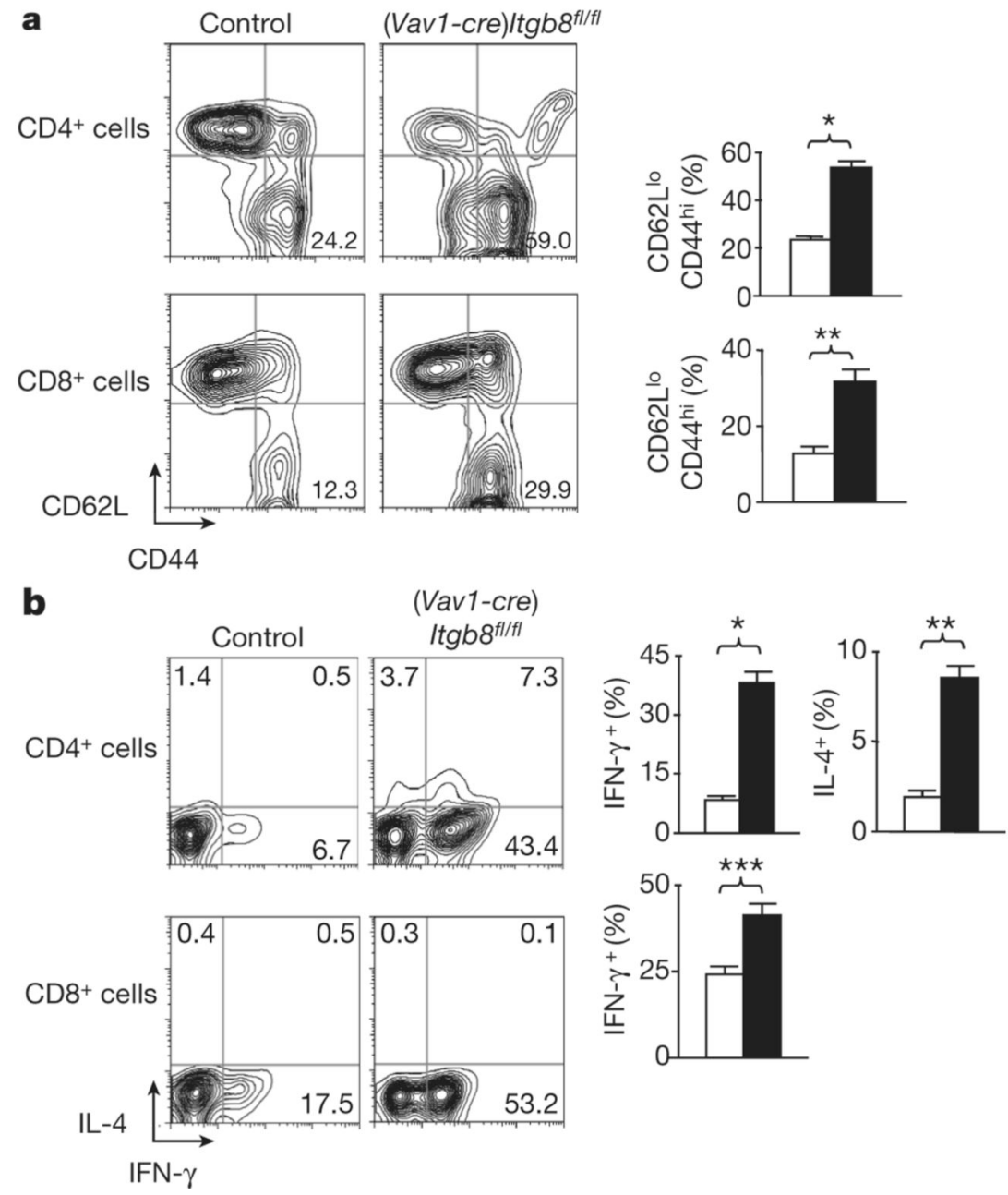

c
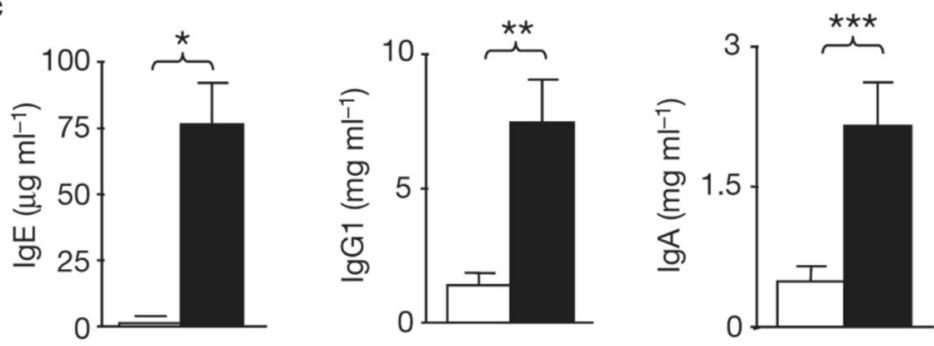

Figure 2. (Vav1-cre)Itgb $8^{f l / f l}$ mice develop enhanced numbers of activated/memory $\mathbf{T}$ cells expressing IL-4 and IFN- $\gamma$, and increased serum IgE, IgG1 and IgA levels

a, Activated/memory $\mathrm{T}$ cells from spleen (CD62L ${ }^{\text {low }}$ CD44high 4 4-6-month-old mice) were analysed by flow cytometry. Representative flow cytometry plots and plotted mean values are shown (white, control; black, (Vavl-cre)Itgb $8^{f l f l}$; $n=14$; asterisk, $P=2.7 \times 10^{-11}$; double asterisk, $P=4.9 \times 10^{-5}$ ). b, IL-4 and IFN- $\gamma$ levels in T cells from spleen were analysed by intracellular flow cytometry. Representative flow cytometry plots and plotted mean values are shown (white, control; black, (Vavl-cre)Itgb $8^{f l f l}$; $n=9$; asterisk, $P=1.8 \times 10^{-8}$; double asterisk, $P=1.8 \times 10^{-7}$; triple asterisk, $P=0.00048$ ). c, ELISA for $\operatorname{IgE}, \operatorname{IgG} 1$ and IgA levels in sera (4-6- 
month-old mice; white, control; black, (Vavl-cre)Itgb ${ }^{f l f f l} ; n=4$; asterisk, $P=0.0028$; double asterisk, $P=0.011$; triple asterisk, $P=0.016$ ). All error bars represent s.e.m. 


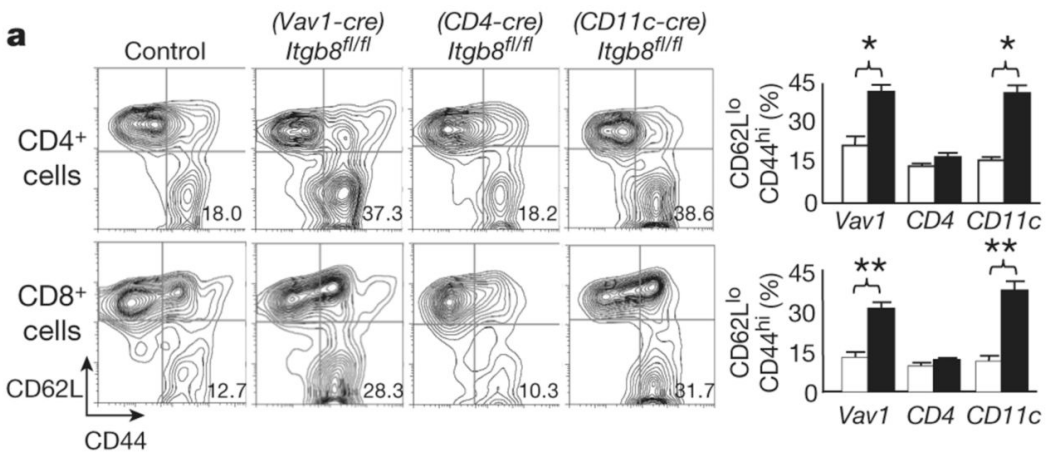

b
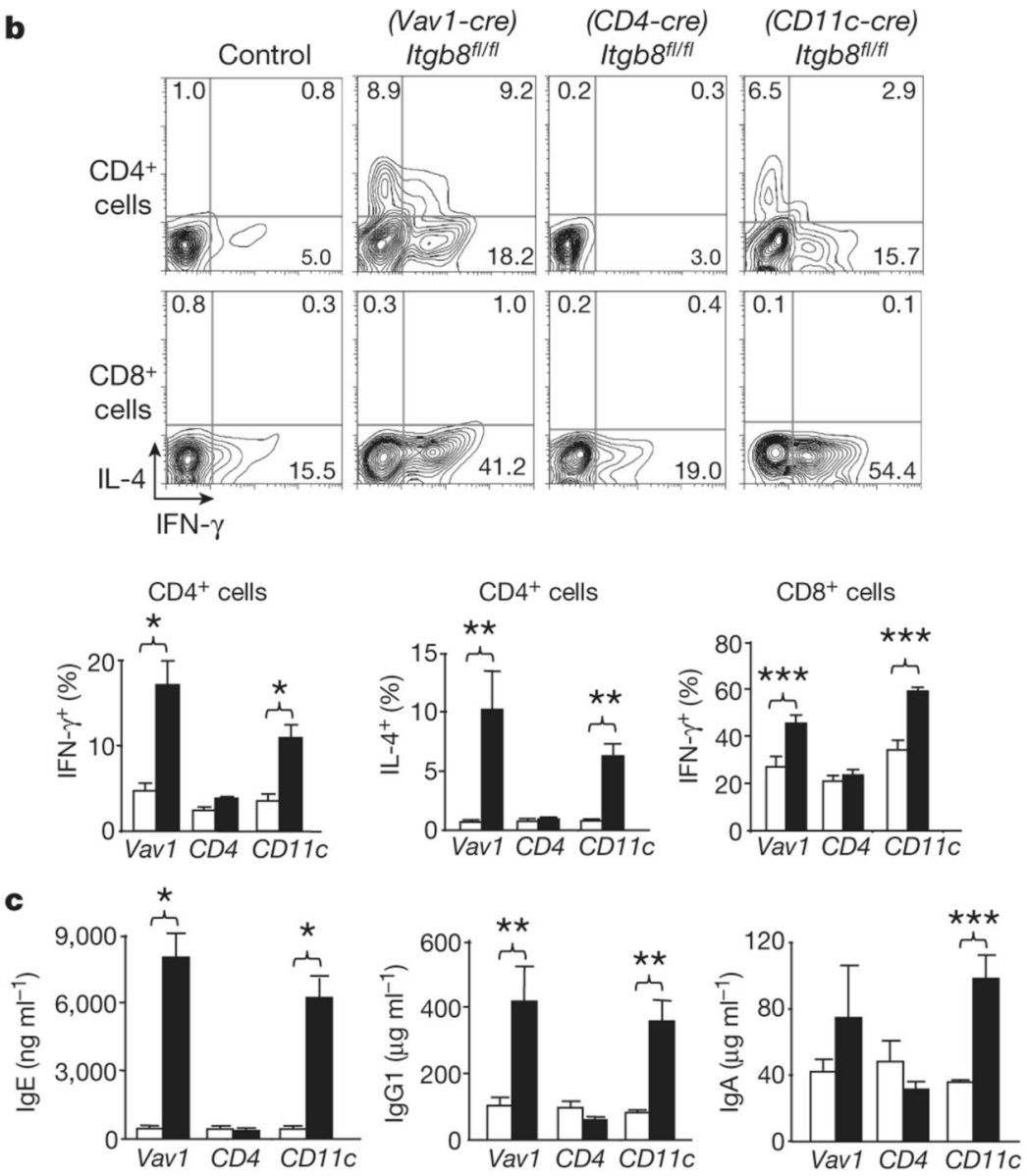

Figure 3. Mice lacking integrin $\beta_{8}$ on dendritic cells develop an identical immune phenotype to mice lacking $\beta$ gintegrin on all leukocytes

a, Activated/memory T cells from spleen (CD62 L ${ }^{\text {low }}$ CD44 4 high, $4-6$-week-old mice) were analysed by flow cytometry. Representative flow cytometry plots and plotted mean values are shown (white, control; black, Itgb 8 conditional knockout; $n=6$ per group; asterisk, $P<8.2 \times 10^{-4}$; double asterisk, $P<1.4 \times 10^{-4}$ ). b, IL-4 and IFN- $\gamma$ levels in T cells from spleen were analysed by intracellular flow cytometry. Representative flow cytometry plots and plotted mean values are shown (white, control; black, Itg $b 8$ conditional knockout; $n=6$ per group; asterisk, $P<0.0063$; double asterisk, $P=0.0055$; triple asterisk, $P=0.0045)$. c, ELISA for IgE, IgG1 and IgA levels in sera (4-6-week-old mice; white, control; black, Itg b8 conditional 
knockout; $n=6$; asterisk, $P<0.0018$; double asterisk, $P<0.016$; triple asterisk, $P=0.0015$ ). All error bars represent s.e.m. 
a

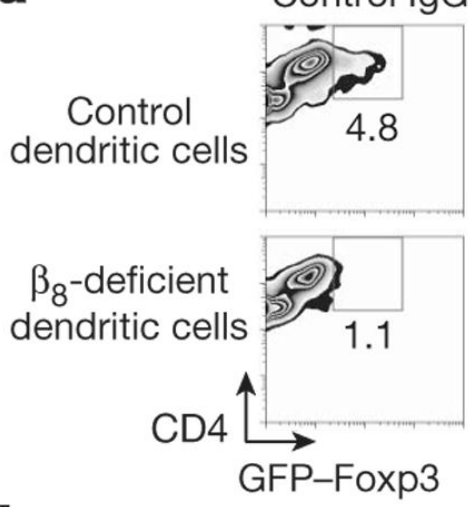

b

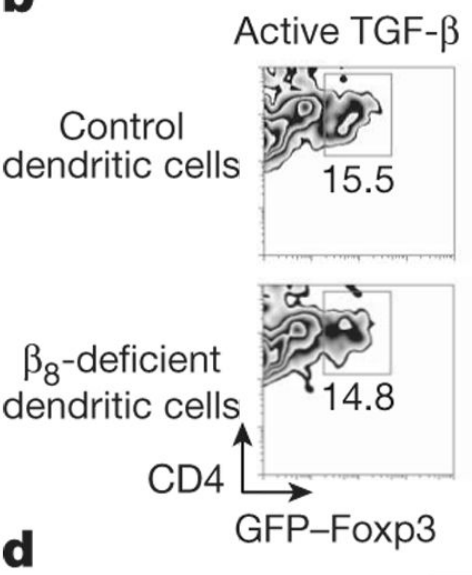

Active TGF- $\beta$

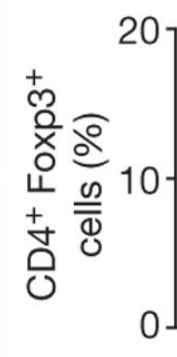

Anti-TGF- $\beta$ Ab
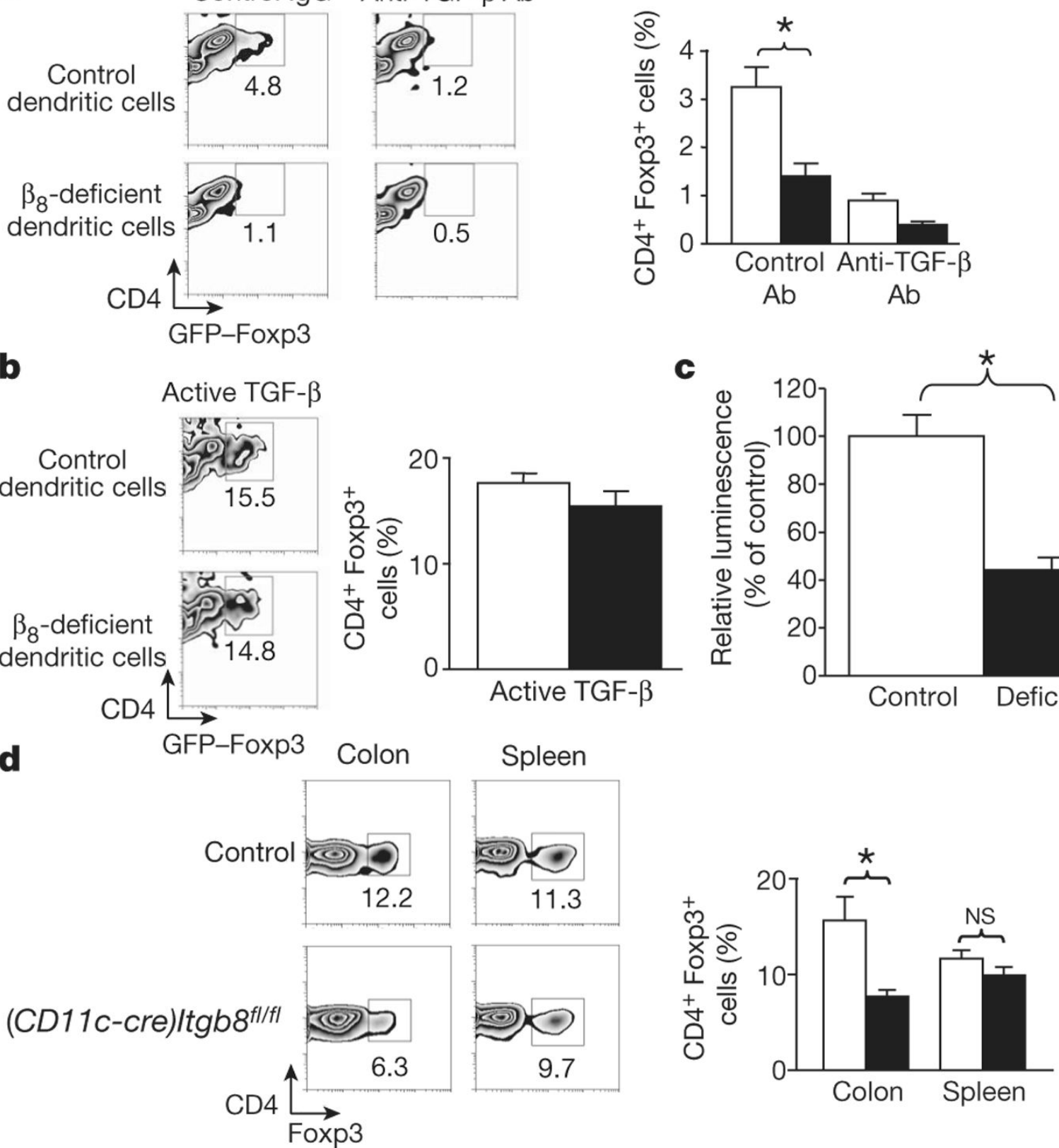

Figure 4. $\beta 8$-deficient dendritic cells fail to induce $T_{R}$ cells in vitro, and (CD11c-cre)Itgb8 ${ }^{f l / f l}$ mice have reduced proportions of $T_{R}$ cells in colonic tissue

$\mathbf{a}, \mathbf{b}$, Induction of $\mathrm{T}_{\mathrm{R}}$ cells $\left(\mathrm{CD} 4^{+} \mathrm{GFP}-\mathrm{Foxp}^{+}\right)$by control or $\beta_{8}$-deficient dendritic cells in the presence of control or anti-TGF- $\beta$ antibody (a) or active TGF- $\beta$ (b). Representative flow cytometry plots and mean data plots (expressed as percentage of $\mathrm{CD}^{+}$cells that expressed GFP-Foxp3) are shown (white, control dendritic cells; black, $\beta_{8}$-deficient dendritic cells; $n=5$; asterisk, $P=0.013$ ). c, TGF- $\beta$ activation by control or $\beta_{8}$-deficient dendritic cells, detected using mink lung reporter cells ${ }^{30}$ (white, control dendritic cells; black, $\beta_{8}$-deficient dendritic cells; $n=6$; asterisk, $P=0.0006)$. d, $\mathrm{T}_{\mathrm{R}}$ cell proportions present in spleen or colonic lamina propria. Representative flow cytometry plots and mean data plots (expressed as percentage of CD4 ${ }^{+}$ 
cells that expressed GFP-Foxp3) are shown (white, control; black, (CD1 lc-cre)Itgb $8^{f l / f l} ; n=6$; asterisk, $P=0.012$ ). NS, not significant. All error bars represent s.e.m. 